\title{
Implementasi Kooperatif NHT Meningkatkan Aktivitas Dan Hasil Belajar Teknik Dasar Passing Kaki Bagian Dalam
}

\author{
Wayan Fitri Suwandewi ${ }^{1}$ \\ Jurusan Penjaskesrek \\ Universitas Pendidikan Ganesha \\ Singaraja, Indonesia \\ e-mail : [fitrisuwandewi46@gmail.com ${ }^{1}$,wayan.artanayasa@undiksha.ac.id]
}

\begin{abstract}
Abstrak
Penelitian ini bertujuan meningkatkan aktivitas dan hasil belajar teknik dasar passing kaki bagian dalam melalui implementasi model NHT pada Peserta didik kelas X A5 SMK Negeri 2 Singaraja Penelitian ini adalah penelitian tindakan kelas, dilaksanakan dalam dua siklus. Subjek penelitian adalah peserta didik kelas X A5 SMK Negeri 2 Singaraja,berjumlah 36 orang. pada siklus I aktivitas belajar siswa didapatkan secara klasikal 7,15 (aktif), dan 8,00 (aktif) pada siklus II. Sedangkan persentase ketuntasan hasil belajar kompetensi pengetahuan pada siklus I yaitu $83,3 \%$ (tuntas) dan $100 \%$ (tuntas) pada siklus II. Peningkatan hasil belajar secara signifikan juga terjadi pada kompetensi sikap dan kompetensi keterampilan. Jadi aktivitas dan hasil belajar teknik dasar passing kaki bagian dalam meningkat melalui implementasi model pembelajaran kooperatif tipe NHT pada peserta didik kelas $\mathrm{X}$ A5 SMK Negeri 2 Singaraja. Disarankan kepada guru PJOK agar menggunakan model NHT karena dapat meningkatkan aktivitas dan hasil belajar teknik dasar passing kaki bagian dalam.
\end{abstract}

Kata Kunci: Kooperatif, NHT, aktivitas, hasil belajar, sepak bola

\begin{abstract}
This study aimed at improving the learning activity and learning outcome of passing football basic technique through the implementation of cooperative learning model type $\mathrm{NHT}$ of students in class X A5 SMK Negeri 2 Singaraja in the academic year of 2018/2019. The present study was a classroom action research which was conducted in two cycle. The subjects of the study were the students of class X A5 SMK Negeri 2 Singaraja, amounted 36 people (18 males and 18 females). The data was analyzed by using descriptive statistics method. According to the result of passing football basic technique learning analysis classically in cycle I was 7,15 (adequately active), improved in cycle II became 8,00 (active). Meanwhile, the learning outcome was acquired classically in cycle I in knowledge aspect $83,3 \%$ (passed), and $100 \%$ (passed) in cycle II. The significant improvement occurred in the behavior knowledge, and skill competence seeing from the result of data analysis classically. Based on the result and discussion it can be concluded that learning activity and learning outcome of passing volleyball basic technique was improved through the implementation of cooperative learning model type NHT of students in class X A5 SMK Negeri 2 Singaraja in the academic year of 2018/2019. It is suggested to the sports teachers to implement cooperative learning model type NHT because it can improve the students' passing footeyball basic technique.
\end{abstract}

Keywords : cooperative, NHT, activity, learning outcomes, football

\section{Pendahuluan}

Kurikulum terus disesuaikan, berbagai pendekatan dan metode pembelajaran disempurnakan, pembelajaran tambahan jam ekstra terus dilakukan, namun hasil belajar pendidikan jasmani, olahraga dan kesehatan (PJOK) belum sesuai dengan harapan. Salah satu penyebabnya adalah pelaksanaan pembelajaran mata pelajaran PJOK sering mengalami masalah. Bagi siswa masalah sering dialami karena sebagian besar siswa sudah beranggapan bahwa PJOK merupakan pelajaran yang memerlukan tenaga besar, perlu kekuatan tubuh yang cukup dan memerlukan keterampilan khusus disamping itu kebanyakan siswa di setiap jenjang pendidikan masih banyak berpandangan bahwa PJOK merupakan mata pelajaran yang sulit dan sering menimbulkan masalah dalam belajar. Padahal berbagai upaya terpadu telah dilakukan pemerintah dan pihak-pihak yang peduli pendidikan dalam rangka meningkatkan kualitas pendidikan, namun semua usaha tersebut belum membuahkan 
hasil yang optimal. Perencanaan pembelajaran yang dibuat dan yang akan disajikan di kelas masih kurang mengarah pada upaya meningkatkan aktivitas dan hasil belajar PJOK siswa.Pada pelajaran PJOK terutama di SMK, siswa cenderung kurang aktif untuk berpartisipasi dalam proses pembelajaran, hal ini terbukti dari aktvitas dan hasil belajar gerak yang diperoleh siswa kurang memuaskan atau belum memenuhi sasaran yang ditunjukkan dengan belum dikuasainya teknik-teknik gerak yang diajarkan. Siswa cenderung menyepelekan pelajarn PJOK, sebab mereka lebih terkonsentrasi pada mata pelajaran yang diujikan pada ujian nasional.

Berdasarkan hasil observasi awal yang dilakukan peneliti pada hari Sabtu, 23 Agustus di kelas X A5 SMK Negeri 2 Singaraja tahun pelajaran 2018/2019, aktivitas belajar 36 orang peserta didik (18 orang perempuan dan 18 orang laki-laki) pada materi teknik dasar passing sepak bola kaki bagian dalam yang diperoleh pada saat observasi tergolong cukup aktif. Dapat dilihat dari komponen aktivitas belajar peserta didik yang terdiri dari kegiatan visual, lisan, mendengarkan, metrik, mental dan emosional. Berdasarkan hasil pengamatan dari keenam komponen aktivitas tersebut didapatkan hasil persentase sebagai berikut: Peserta didik pada kategori sangat aktif tidak ada $(0 \%), 14$ orang $(38,9 \%)$ berada dalam kategori aktif, 17 orang $(47,2 \%)$ berada dalam cukup aktif, 5 orang $(13,9 \%)$ berada dalam kategori kurang aktif, dan tidak ada orang $(0 \%)$ berada dalam kategori sangat kurang aktif, dengan persentase ketuntasan 14 orang $(38,9 \%)$ dengan keterangan aktif dan 22 orang $(61,1 \%)$ dengan keterangan tidak aktif. Berdasarkan data di atas, maka peneliti bisa mengetahui rata-rata klasikal aktivitas belajar teknik dasar passing kaki bagian dalam sebesar 5,8 yang tergolong dalam kategori cukup aktif. Sehingga dapat diketahui berapa banyak peserta didik yang tuntas dan peserta didik tidak tuntas.

Jika dilihat dari hasil observasi, ketuntasan hasil belajar untuk aspek pengetahuan, peserta didik yang berada pada kategori baik 16 orang $(44,4 \%)$, dan pada kategori cukup baik 20 orang (55,6\%). Jadi jumlah siswa yang tuntas dalam teknik dasar passing Kaki bagian dalam aspek pengetahuan secara klasikal yaitu 16 orang $(44,4 \%)$ tuntas dan 20 orang $(55,6 \%)$ tidak tuntas, Dengan menganalisa data hasil belajar kompetensi pengetahuan peserta didik secara keseluruhan terlihat belum memenuhi sasaran, karena belum memenuhi standar kriteria ketuntasan minimal (KKM) sekolah untuk mata pelajaran PJOK sebesar 70\% ketuntasan klasikal. Permasalahan yang muncul pada aspek pengetahuan adalah kurangnya pemahaman peserta didik mengenai teknik dasar passing kaki bagian dalam, hal ini disebabkan oleh kurangnya perhatian peserta didik pada saat guru menjelaskan dan pembelajaran masih dominan guru yang lebih aktif.

Ketuntasan hasil belajar untuk aspek keterampilan, tidak ada peserta didik yang berada pada kategori sangat baik, peserta didik yang kategori baik sebanyak 17 orang $(47,2 \%)$, cukup baik sebanyak 19 orang $(52,8 \%)$ dan tidak ada peserta didik pada kriteria kurang baik. Jadi jumlah siswa yang tuntas dalam teknik dasar passing kaki bagian dalam aspek keterampilan secara klasikal yaitu 17 orang $(47,2 \%)$ tuntas dan 19 orang $(52,8 \%)$ tidak tuntas, dengan nilai rata-rata hasil belajar secara klasikal yaitu 79,5 yang berada pada kategori Cukup. Dengan menganalisa data hasil belajar kompetensi keterampilan peserta didik secara keseluruhan terlihat hasil belajar kompetensi keterampilan belum memenuhi target, karena belum memenuhi standar KKM sekolah untuk mata pelajaran PJOK sebesar $70 \%$ ketuntasan klasikal.

Ketuntasan hasil belajar untuk aspek sikap, tidak ada peserta didik yang berada pada kategori sangat baik, peserta didik dengan kategori baik sebanyak 36 orang (100\%), dan tidak ada peserta didik dengan kategori cukup baik dan kurang baik. Jadi jumlah siswa yang tuntas dalam teknik dasar passing kaki bagian dalam aspek sikap secara klasikal yaitu 36 orang $(100 \%)$ tuntas, dengan hasil nilai rata-rata hasil belajar secara klasikal yaitu 83,6 yang berada pada kategori baik. Dengan menganalisa data hasil belajar kompetensi sikap peserta didik secara keseluruhan terlihat sudah memenuhi ketuntasan, karena sudah memenuhi standar KKM sekolah untuk mata pelajaran PJOK sebesar $70 \%$ ketuntasan klasikal. Jadi adanya peserta didik yang bermasalah pada hasil belajar disebabkan oleh (1) dari segi kerjasama, peserta didik masih kurang untuk melakukan kerjasama didalam pembelejaran dan 
cenderung individual, (2) dari segi disiplin, peserta didik masih banyak yang berpakaian kurang rapi, terlambat saat datang dan melakukan kegiatan diluar materi saat pembelajaran, (3) dari segi tanggung jawab, peserta didik kurang bertanggung jawab didalam pemakain sarana pembelajaran.

Jadi jika dilihat dari rata-rata aktivitas dan hasil belajar teknik dasar passing kaki bagian dalam di atas dapat disimpulkan bahwa, aktivitas dan hasil belajar teknik dasar passing kaki bagian dalam pada kelas X A5 SMK Negeri 2 Singaraja tidak tuntas. Hal ini disebabkan implementasi model pembelajaran yang belum efektif terhadap materi yang disajikan. Model pembelajaran yang diimplementasikan belum melibatkan atau merangsang peserta didik untuk lebih aktif dan kreatif selama proses pembelajaran berlangsung. Berdasarkan permasalahan di atas, peneliti mencoba memberikan salah satu alternatif pemecahan masalah yaitu dengan menerapkan model pembelajaran kooperatif tipe Numbered Head Together (NHT) dalam pembelajaran PJOK pada materi teknik dasar passing kaki bagian dalam. Ketertarikan peneliti menerapkan model pembelajaran kooperatif tipe NHT ini karena (1) model pembelajaran kooperatif dengan tipe NHT adalah model pembelajaran yang sederhana, sehingga model pembelajaran kooperatif ini cocok diterapkan pada peserta didik kelas X A5 SMK Negeri 2 Singaraja yang belum pernah melakukan pembelajaran kooperatif tipe NHT, (2) pada model pembelajaran ini peserta didik lebih banyak mempunyai kesempatan diskusi kelompok, masing-masing peserta didik memberikan partisipasinya secara maksimal dan setiap peserta didik mempunyai tanggung jawab perseorangan untuk menguasai materi dengan sebaik-baiknya, (3) model pembelajaran kooperatif dengan tipe NHT mengajak peserta didik untuk belajar aktif dan berani dalam mengeluarkan pendapat dalam diskusi kelompok. Apabila ada suatu konsep yang belum dimengerti dan dipahaminya, peserta didik dapat saling isi mengisi dengan peserta didik lain, saling bertukar pikiran sehingga diharapkan konsep yang dimiliki peserta didik benar-benar dapat dipahami dengan baik. Suasana belajar akan lebih kondusif, yang akhirnya berpengaruh terhadap aktivitas dan hasil belajar.

Pemilihan tentang model pembelajaran NHT ini juga dikuatkan oleh hasil penelitian dari peneliti-peneliti sebelumnya diantaranya (1) Penelitian yang dilakukan oleh Sanjaya, I.P.E.Y (2013 :123) dalam skripsinya yang menyimpulkan motivasi dan hasil belajar teknik Lompat jauh gaya menggantungmeningkat melalui penerapan model pembelajaran kooperatif tipe NHT pada peserta didik kelas X.5 SMA Negeri 1 Negara tahun pelajaran 2012/2013, (2) Penelitian yang dilakukan oleh Bawa, I.M.L (2012:116) dalam skripsinya yang menyimpulkan aktivitas dan hasil belajar teknik dasar passing sepak bola meningkat melalui penerapan model pembelajaran kooperatif tipe NHT pada peserta didik kelas X.1 SMK Negeri 2 Singaraja tahun pelajaran 2011/2012, (3) Penelitian yang dilakukan oleh Tirtawati, N.W (2013:103) dalam skripsinya yang menyimpulkan motivasi dan hasil belajar lompat jauh gaya menggantungmeningkat melalui penerapan model pembelajaran kooperatif tipe NHT pada peserta didik kelas XI IPA 3SMA Negeri 2 Bangli tahun pelajaran 2012/2013.

Berdasarkan uraian di atas, maka peneliti bermaksud mengadakan penelitian dengan judul "Implementasi Model Pembelajaran Kooperatif Tipe NHT untuk Meningkatkan Aktivitas dan Hasil Belajar Teknik Dasar Passing Kaki Bagian Dalam pada Peserta Didik Kelas X A5 SMK Negeri 2 Singaraja Tahun Pelajaran 2018/2019".

\section{METODE PENELITIAN}

Jenis penelitian yang digunakan adalah penelitian tindakan kelas. Menurut Arikunto dkk, (2008: 2-3) dikarenakan ada tiga kata yang membentuk pengertian tersebut, maka ada tiga pengertian yang dapat diterangkan yaitu (1) Penelitian, menunjuk pada suatu kegiatan mencermati suatu objek dengan menggunakan cara dan aturan metodologi tertentu untuk memproleh data atau informasi yang bermaanfat dalam meningkatkan mutu suatu hal yang menarik minat dan penting bagi peneliti, (2) Tindakan, menunjuk pada sesuatu gerak kegiatan yang disengaja dilakukan dengan tujuan tertentu, (3) Kelas, dalam hal ini tidak terikat pada pengertian ruang kelas, tetapi dalam pengertian yang lebih spesifik, (4) dengan menggabungkan batasan pengertian tiga kata inti, yaitu (1) penelitian, (2) tindakan, (3) kelas, 
dapat disimpulkan bahwa penelitian tindakan kelas merupakan suatu pencermatan terhadap kegiatan belajar berupa sebuah tindakan, yang sengaja dimunculkan dan terjadi dalam sebuah kelas secara bersama.

Oja dan Smulyan membedakan adanya empat bentuk penelitian tindakan, yaitu (1) guru sebagai peneliti, (2) penelitian Tindakan Kolaboratif, (3) simultan-Terintregasi, (4) administrasi Sosial Eksperimental (Kanca, I Nyoman, 2010: 115). Dalam penelitian ini bentuk penelitian tindakan yang digunakan adalah guru sebagai peneliti. Karena peneliti sudah menjadi guru, maka dalam penelitian ini menggunakan bentuk penelitan peneliti sebagai guru, karena dalam bentuk PTK yang memandang guru sebagai peneliti mempunyai ciri-ciri penting yaitu sangat berperannya guru itu sendiri dalam proses PTK. Tujuan utama PTK adalah untuk memperbaiki dan meningkatkan mutu profesional guru didalam proses pembelajaran.

\section{Hasil dan Pembahasan}

Penelitian ini dilaksanakan dari hari rabu tanggal 13 September 2018 sampai dengan hari Sabtu tanggal 27 September 2018, yang dilaksanakan setiap pukul 05.30-07.15 wita, bertempat di lapangan Taman Kota Singaraja, dengan subjek penelitiannya adalah peserta didik kelas X A5 SMK Negeri 2 Singaraja Tahun Pelajaran 2018/2019 yang berjumlah 36 orang yang terdiri dari 18 orang putra dan 18 orang putri. Penelitian ini dilaksanakan sebanyak dua siklus, disetiap siklus terdapat dua kali pertemuan. Siklus I pertemuan pertama dilaksanakan pada hari sabtu 13 September 2018 untuk pengambilan data aktivitas belajar peserta didik dan pertemuan kedua dilaksanakan pada hari rabu 20 September 2018 untuk pengambilan data aktivitas dan hasil belajar peserta didik. Sedangkan siklus II pertemuan pertama dilaksanakan pada hari rabu 27 September 2018 untuk pengambilan data aktivitas belajar peserta didik dan pertemuan kedua dilaksanakan pada hari sabtu 04 Oktober 2018 untuk pengambilan data aktivitas dan hasil belajar peserta didik, yang bertempat di lapangan Taman Kota Singaraja, untuk pengambilan data aktivitas dan hasil belajar peserta didik melibatkan seorang Observer yaitu guru PJOK SMK Negeri 2 Singaraja.

Tabel 1. Hasil Analisis Data Aktivitas Belajar Teknik Dasar Passing Kaki Bagian Dalam pada Siklus I

\begin{tabular}{|c|c|c|c|c|c|}
\hline No & Kriteria & $\begin{array}{c}\text { Jumlah } \\
\text { Peserta } \\
\text { Dididk }\end{array}$ & Persentase & Kategori & Keterangan \\
\hline 1 & $\bar{X} \geq 9$ & - & - & Sangat aktif & \multirow{2}{*}{$\begin{array}{l}28 \quad \text { Orang } \\
\text { Peserta Dididk } \\
\text { Aktif (77\%) }\end{array}$} \\
\hline 2 & $7 \leq \bar{X}<9$ & 28 & $77 \%$ & Aktif & \\
\hline 3 & $5 \leq \bar{X}<7$ & 8 & $22 \%$ & Cukup Aktif & $8 \quad$ Orang \\
\hline 4 & $3 \leq \bar{X}<5$ & - & - & Kurang Aktif & \multirow{2}{*}{$\begin{array}{ll}\text { Peserta } & \text { Didik } \\
\text { Tidak } & \text { Aktif } \\
(22 \%) & \end{array}$} \\
\hline 5 & $\bar{X}<3$ & - & - & Sangat Kurang Aktif & \\
\hline & Total & 36 & $100 \%$ & & $\begin{array}{c}36 \text { Peserta } \\
\text { Dididk (100\%) }\end{array}$ \\
\hline
\end{tabular}

Dari tabel 1 di atas dapat dilihat bahwa, peserta didik yang berada pada kategori sangat aktif tidak ada, kategori aktif 28 orang (77\%), kategori cukup aktif 8 orang (22\%), kurang aktif tidak ada begitu juga dengan siswa yang sangat kurang aktif. Dari hasil analisis data diatas maka dapat dikatakan bahwa implementasi model pembelajaranan kooperatif tipe NHT efektif untuk meningkatkan aktivitas belajar teknik dasar passing kaki bagian dalam, hal ini dapat dilihat dari presentase ketuntasan belajar yang mencapai $77 \%$ (28 orang). 
Tabel 2. Hasil Analisis Data Hasil Belajar Aspek Pengetahuan Teknik Dasar Passing Kaki Bagian Dalam pada Siklus I.

\begin{tabular}{cccccc}
\hline No & $\begin{array}{c}\text { Jumlah } \\
\text { Peserta Didik }\end{array}$ & Kriteria & Predikat & $\begin{array}{c}\text { Presentase } \\
(\%)\end{array}$ & Keterangan \\
\hline 1 & 6 & Sangat Baik & A & $16,7 \%$ & 30 orang \\
2 & 24 & Baik & B & $66,6 \%$ & $(83,3 \%)$ tuntas \\
3 & 6 & Cukup & C & $16,7 \%$ & 6 orang \\
& & Kurang & D & - & $(16,7 \%)$ belum \\
4 & - & & & & tuntas \\
\hline
\end{tabular}

Jumlah

36

$100 \%$

Berdasarkan tabel 2, hasil belajar aspek pengetahuan pada siklus I dengan materi teknik dasar passing kaki bagian dalam, diperoleh data hasil belajar dengan kategori individu sebagai berikut, 6 orang kategori sangat baik (16,7\%), 24 orang $(66,6 \%)$ memperoleh nilai dengan kategori baik, 6 orang $(16,7 \%)$ memperoleh nlai dengan kategori cukup, dan 0 orang $(0 \%)$ memperoleh nilai dengan kategori kurang. Jadi dapat diperoleh 30 orang $(83,3 \%)$ dengan keterangan tuntas, dan 6 orang $(16,7 \%)$ dengan keterangan belum tuntas.

Tabel 3 Hasil Analisis Data Hasil Belajar Aspek Sikap Teknik Dasar Passing Kaki Bagian Dalam pada siklus I

\begin{tabular}{|c|c|c|c|c|c|}
\hline No & $\begin{array}{c}\text { Jumlah Peserta } \\
\text { Didik }\end{array}$ & Kriteria & Predikat & $\begin{array}{c}\text { Presentase } \\
(\%)\end{array}$ & Keterangan \\
\hline 1 & 9 & $\begin{array}{c}\text { Sangat } \\
\text { Baik }\end{array}$ & $A$ & $25 \%$ & \multirow{2}{*}{$\begin{array}{c}36 \text { orang } \\
(100 \%) \text { tuntas }\end{array}$} \\
\hline 2 & 27 & Baik & B & $75 \%$ & \\
\hline 3 & - & Cukup & C & - & \\
\hline 4 & - & Kurang & $D$ & - & \\
\hline Jumlah & 36 & & & $100 \%$ & \\
\hline
\end{tabular}

Berdasarkan tabei 3 di atas, hasil belajar aspek sikap pada siklus I dengan materi teknik dasar passing kaki bagian dalam, diperoleh data hasil belajar dengan kategori individu sebagai berikut, peserta didik dengan kategori sangat baik 9 orang (25\%), 27 orang (75\%) memperoleh nilai dengan kategori baik, tidak ada peserta didik dengan kategori cukup, tidak ada peserta didik yang memperoleh nilai dengan kategori kurang.

Tabel 4. Hasil Analisis Data Hasil Belajar Aspek Keterampilan Teknik Dasar Passing Kaki Bagian Dalam pada siklus I

\begin{tabular}{cccccc}
\hline No & $\begin{array}{c}\text { Jumlah } \\
\text { Peserta Didik }\end{array}$ & Kriteria & Predikat & $\begin{array}{c}\text { Presentase } \\
(\%)\end{array}$ & Keterangan \\
\hline 1 & 8 orang & Sangat Baik & A & $22,2 \%$ & 29 orang \\
2 & 21 orang & Baik & B & $58,3 \%$ & $(80,6 \%)$ tuntas \\
3 & 7 orang & Cukup & C & $19,4 \%$ & 7 orang \\
4 & - & Kurang & - & - & $(19,4 \%)$ belum tuntas \\
\hline Jumlah & $\mathbf{3 6}$ orang & & & $\mathbf{1 0 0 \%}$ & \\
\hline
\end{tabular}


Berdasarkan tabel 4, hasil belajar aspek keterampilan pada siklus I dengan materi teknik dasar passing kaki bagian dalam, diperoleh data hasil belajar dengan kategori individu sebagai berikut, 8 orang $(22,2 \%)$ kategori sangat baik, 21 orang $(58,3 \%)$ memperoleh nilai dengan kategori baik, 7 orang $(19,4 \%)$ memperoleh nilai dengan kategori cukup, dan tidak ada peserta didik yang memperoleh nilai dengan kategori kurang. Jadi diperoleh data 29 orang $(80,6 \%)$ dengan keterangan tuntas, dan 7 orang $(19,4 \%)$ dengan keterangan belum tuntas.

Tabel 5. Hasil Analisis Data Aktivitas Belajar Teknik Dasar Passing Kaki Bagian Dalam pada Siklus II.

\begin{tabular}{|c|c|c|c|c|c|}
\hline No & Kriteria & $\begin{array}{c}\text { Jumlah } \\
\text { Peserta } \\
\text { Dididk }\end{array}$ & Persentase & Kategori & Keterangan \\
\hline 1 & $X \geq 9$ & 3 orang & $8,33 \%$ & Sangat aktif & $\begin{array}{c}3 \text { Orang }(8,33 \%) \\
\text { sanqat Aktif }\end{array}$ \\
\hline 2 & $7 \leq \bar{X}<9$ & 31 orang & $86,1 \%$ & Aktif & $\begin{array}{c}31 \text { Orang }(86,1 \%) \\
\text { Aktif }\end{array}$ \\
\hline 3 & $5 \leq \bar{X}<7$ & 2 orang & $5,56 \%$ & Cukup Aktif & $\begin{array}{l}2 \text { Orang }(5,56 \%) \\
\text { cukup Aktif }\end{array}$ \\
\hline 4 & $3 \leq \bar{X}<5$ & - & - & Kurang Aktif & \\
\hline 5 & $\bar{X}<3$ & - & - & $\begin{array}{c}\text { Sangat } \\
\text { Kurang Aktif }\end{array}$ & \\
\hline & Total & 36 orang & $100 \%$ & & 36 orang $(100 \%)$ \\
\hline
\end{tabular}

Dari tabel 5 di atas dapat dilihat bahwa, peserta didik yang berada pada kategori sangat aktif 3 orang $(8,33 \%)$, kategori aktif 31 orang $(86,1 \%)$, kategori cukup aktif 2 orang $(5,56 \%)$, dan tidak ada peserta didik yang berada dalam kategori kurang aktif, dan sangat kurang aktif.

Tabel 6. Hasil Analisis Data Hasil Belajar Aspek Pengetahuan Teknik Dasar Passing Kaki Bagian Dalam pada Siklus II

\begin{tabular}{cccccc}
\hline No & $\begin{array}{c}\text { Jumlah } \\
\text { Peserta Didik }\end{array}$ & Kriteria & Predikat & $\begin{array}{c}\text { Presentase } \\
(\%)\end{array}$ & Keterangan \\
\hline 1 & 29 orang & Sangat Baik & A & $80,56 \%$ & 36 orang \\
2 & 7 orang & Baik & B & $19,44 \%$ & $(100 \%)$ tuntas \\
3 & - & Cukup & C & - & - \\
4 & - & Kurang Baik & D & - & \\
\hline Jumlah & $\mathbf{3 6}$ orang & & & $\mathbf{1 0 0 \%}$ & \\
\hline
\end{tabular}

Berdasarkan tabel 6, hasil belajar aspek pengetahuan pada siklus II dengan materi teknik dasar passing kaki bagian dalam, diperoleh data hasil belajar dengan kategori individu sebagai berikut, 29 Orang (80,56\%) dalam kategori sangat baik, 7 orang $(19,44 \%)$ memperoleh nilai dengan kategori baik, dan tidak ada peserta didik yang memperoleh nilai dengan kategori cukup dan kurang baik. 
Tabel 7. Hasil Analisis Data Hasil Belajar Aspek Sikap Teknik Dasar Passing Kaki Bagian Dalam pada Siklus II

\begin{tabular}{cccccc}
\hline No & $\begin{array}{c}\text { Jumlah } \\
\text { Peserta } \\
\text { Didik }\end{array}$ & Kriteria & Predikat & $\begin{array}{c}\text { Presentase } \\
\text { (\%) }\end{array}$ & Keterangan \\
\hline 1 & 16 orang & $\begin{array}{c}\text { Sangat } \\
\text { Baik }\end{array}$ & A & $44,4 \%$ & 36 orang \\
2 & 20 orang & Baik & B & $55,6 \%$ & $(100 \%)$ tuntas \\
3 & - & Cukup & C & - & - \\
4 & - & Kurang & D & - & \\
\hline Jumlah & $\mathbf{3 6}$ orang & & & $\mathbf{1 0 0 \%}$ & \\
\hline
\end{tabular}

Berdasarkan tabei 7, hasil belajar aspek sikap pada siklus II dengan materi teknik dasar passing kaki bagian dalam, diperoleh data hasil belajar dengan kategori individu sebagai berikut 16 orang $(44,4 \%)$ dengan kategori sangat baik, 20 orang $(55,6 \%)$ memperoleh nilai dengan kategori baik, tidak ada peserta didik yang memperoleh nilai dengan kategori cukup maupun yang memperoleh nilai dengan kategori kurang.

Tabel 8. Hasil Analisis Data Hasil Belajar Aspek Keterampilan Teknik Dasar Passing Kaki Bagian Dalam pada Siklus II

\begin{tabular}{|c|c|c|c|c|c|}
\hline No & $\begin{array}{c}\text { Jumlah } \\
\text { Peserta } \\
\text { Didik }\end{array}$ & Kriteria & Predikat & $\begin{array}{c}\text { Presentase } \\
\text { (\%) }\end{array}$ & Keterangan \\
\hline 1 & 17 orang & $\begin{array}{c}\text { Sangat } \\
\text { Baik }\end{array}$ & $A$ & $47,22 \%$ & \multirow{2}{*}{$\begin{array}{c}36 \text { orang } \\
(100 \%) \text { tuntas }\end{array}$} \\
\hline 2 & 19 orang & Baik & $B$ & $52,78 \%$ & \\
\hline 3 & - & Cukup & C & - & \\
\hline 4 & - & Kurang & $\mathrm{D}$ & - & \\
\hline Jumlah & 36 orang & & & $100 \%$ & \\
\hline
\end{tabular}

Berdasarkan tabel 8, hasil belajar aspek keterampilan pada siklus II dengan materi teknik dasar passing kaki bagian dalam, diperoleh data hasil belajar dengan kategori individu sebagai berikut, 17 orang $(47,22 \%)$ dalam kategori sangat baik, 19 orang $(52,78 \%)$ dalam kategori baik, dan tidak ada peserta didik yang memperoleh nilai dengan kategori cukup dan kurang.

Tabel 9 Ringkasan Data Aktivitas Belajar Teknik Dasar Passing Kaki Bagian Dalam Peserta Didik Dari Siklus I sampai dengan Siklus II.

\begin{tabular}{cccc} 
No Tahapan & $\begin{array}{c}\text { Aktivitas Belajar } \\
\text { Klasikal }\end{array}$ & $\begin{array}{c}\text { Keaktifan Peserta } \\
\text { Didik (Orang) }\end{array}$ & $\begin{array}{c}\text { Peningkatan } \\
\text { Aktivitas Belajar } \\
\text { Siklus I ke Siklus II }\end{array}$ \\
\hline
\end{tabular}




$\left.\begin{array}{ccc}\text { 1. Siklus I } & 7,15 & \begin{array}{c}28 \text { orang }(77 \%) \\ \text { Sudah aktif } \\ 33 \text { orang }(94,43 \%) \\ \text { Sudah aktif }\end{array}\end{array}\right\}$ Orang $(13,89 \%)$

Berdasarkan Tabel 9, data aktivitas belajar teknik dasar passing kaki bagian dalam pada peserta didik kelas X A5 SMK Negeri 2 Singaraja dapat disampaikan bahwa, peserta didik yang sudah aktif pada siklus I, 28 orang (77\%). Karena pada siklus I aktivitas peserta didik masih perlu ditingkatkan, sehingga pada siklus II kembali diberikan tindakan. Setelah diberikan tindakan pada siklus II, aktivitas belajar peserta didik meningkat menjadi 33 orang $(94,43 \%)$ yang aktif . dari siklus I ke Siklus II terjadi peningkatan sebanyak 5 orang $(13,89 \%)$.

Tabel 10. Ringkasan Data Hasil Belajar Teknik Dasar Passing Kaki Bagian Dalam Aspek Pengetahuan Peserta Didik Kelas X A5 SMK Negeri 2 Singaraja dari Siklus I sampai dengan Siklus II.

\begin{tabular}{|c|c|c|c|c|}
\hline No & Tahapan & $\begin{array}{l}\text { Persentase } \\
\text { Ketuntasan } \\
\text { Hasil Belajar }\end{array}$ & $\begin{array}{c}\text { Ketuntasan Peserta } \\
\text { Didik }\end{array}$ & $\begin{array}{l}\text { Peningkatan Hasil } \\
\text { Belajar Aspek } \\
\text { Pengetahuan } \\
\text { Siklus I ke Siklus II }\end{array}$ \\
\hline 1. & Siklus I & $\begin{array}{c}30 \text { Orang } \\
(83,3 \%)\end{array}$ & Tuntas & \\
\hline 2. & Siklus II & $\begin{array}{l}36 \text { Orang } \\
(100 \%)\end{array}$ & Tuntas & 6 Orang $(16,67 \%)$ \\
\hline
\end{tabular}

Berdasarkan tabel 4.10 hasil analisis data hasil belajar aspek pengetahuan teknik dasar passing kaki bagian dalam pada peserta didik kelas X A5 SMK Negeri 2 Singaraja dapat disampaikan bahwa, persentase ketuntasan hasil belajar aspek pengetahuan peserta didik pada siklus I sebesar 30 orang (83,3\%). Karena pada siklus I masih ada peserta didik yang belum tuntas maka diberikan tindakan pada siklus II. Setelah diberikan tindakan pada siklus II ketuntasan hasil belajar peserta didik meningkat dari siklus I, sehingga jumlah ketuntasan hasil belajar aspek pengetahuan peserta didik pada siklus II menjadi 36 orang (100\%). Dari hasil analisis data tersebut, dapat dilihat peningkatan ketuntasan hasil belajar aspek pengetahuan yang terjadi dari siklus I ke siklus II sebanyak 6 orang (16,67\%).

Tabel 11. Ringkasan Data Hasil Belajar Teknik Dasar Passing Kaki Bagian dalam Aspek Sikap Peserta Didik Kelas X A5 SMK Negeri 2 Singaraja dari Siklus I sampai dengan

\begin{tabular}{|c|c|c|c|c|}
\hline No & Tahapan & $\begin{array}{c}\text { Persentase } \\
\text { Ketuntasan Hasil } \\
\text { Belajar }\end{array}$ & $\begin{array}{c}\text { Ketuntasan Peserta } \\
\text { Didik }\end{array}$ & $\begin{array}{l}\text { Peningkatan Hasil } \\
\text { Belajar Aspek Sikap } \\
\text { Siklus I ke Siklus II }\end{array}$ \\
\hline 1. & Siklus I & 36 Orang $(100 \%)$ & Tuntas & 36 Orang $(100 \%)$ \\
\hline 2. & Siklus II & 36 Orang $(100 \%)$ & Tuntas & \\
\hline
\end{tabular}

Berdasarkan tabel 4.11 hasil analisis data hasil belajar aspek sikap teknik dasar passing kaki bagian dalam pada peserta didik kelas X A5 SMK Negeri 2 Singaraja dapat disampaikan bahwa, tingkat ketuntasan hasil belajar aspek sikap peserta didik pada siklus I sebanyak 36 orang (100\%). Karena pada siklus I tidak ada peserta didik yang belum tuntas, apalagi ketuntasan peeserta didik masih dalam kategori cukup, maka diberikan tindakan pada siklus 
II. Setelah diberikan tindakan pada siklus II ketuntasan hasil belajar aspek sikap teknik dasar passing kaki bagian dalam peserta didik masih tetap 36 orang tuntas ( $100 \%$ ).

Tabel 4.12Ringkasan Data Hasil Belajar Teknik Dasar Passing Kaki Bagian dalam Aspek Keterampilan Peserta Didik Kelas X A5 SMK Negeri 2 Singaraja dari Siklus I sampai dengan Siklus II.

$\left.\begin{array}{ccccc}\hline \text { No } & \text { Tahapan } & \begin{array}{c}\text { Persentase } \\ \text { Ketuntasan Hasil } \\ \text { Belajar }\end{array} & \begin{array}{c}\text { Ketuntasan Peserta } \\ \text { Didik }\end{array} & \begin{array}{c}\text { Peningkatan Hasil } \\ \text { Belajar Aspek } \\ \text { Keterampilan } \\ \text { Siklus I ke Siklus II }\end{array} \\ \hline \text { 1. } & \text { Siklus I } & \text { 29 Orang }(80,6 \%) & \text { Tuntas } \\ \text { 2. } & \text { Siklus II } & \text { 36 Orang (100\%) } & \text { Tuntas }\end{array}\right\}$ Orang (19,4\%)

Berdasarkan tabel 4.12 hasil analisis data hasil belajar aspek keterampilan teknik dasar passing kaki bagian dalam pada peserta didik kelas X A5 SMK Negeri 2 Singaraja dapat disampaikan bahwa, tingkat ketuntasan hasil belajar aspek keterampilan peserta didik pada siklus I sebanyak 29 orang $(80,6 \%)$. Karena pada siklus I masih ada peserta didik yang belum tuntas, apalagi ketuntasan peserta didik masih dalam kategori cukup, maka diberikan tindakan pada siklus II. Setelah diberikan tindakan pada siklus II ketuntasan hasil belajar aspek keterampilan teknik dasar passing kaki bagian dalam peserta didik meningkat dari siklus I, sehingga jumlah ketuntasan hasil belajar aspek keterampilan peserta didik pada siklus II menjadi 36 orang (100\%). Dari hasil analisis data tersebut, dapat dilihat peningkatan ketuntasan hasil belajar aspek keterampilan yang terjadi dari siklus I ke siklus II sebanyak 7 orang $(19,4 \%)$.

Berdasarkan hasil analisis data dari implementasi model pembelajaran kooperatif tipe NHT yang bertujuan untuk meningkatkan aktivitas dan hasil belajar teknik dasar passing kaki bagian dalam, dimana hasil penelitian aktivitas belajar peserta didik pada siklus I terhadap pembelajaran PJOK khususnya pada materi teknik dasar passing kaki bagian dalam secara klasikal berada pada kategori cukup aktif. Dengan memperhatikan aktivitas dan hasil belajar teknik dasar passing kaki bagian dalam siklus I, peneliti melanjutkan ke siklus II dengan melihat permasalahan-permasalahan pada siklus I. Hal ini terbukti dari refleksi dari siklus I yang masih terdapat permasalahan-permasalahan dalam pelaksanaan tindakan.

Adapun permasalahan-permasalahan yang dihadapi dalam pembelajaran pada siklus I yaitu: (1) peserta didik kurang mendengarkan penjelasan dari peneliti tentang teknik dasar passing kaki bagian dalam (2) peserta didik kurang memperhatikan demonstrasi yang diperagakan oleh peneliti tentang teknik dasar passing kaki bagian dalam, (3) peserta didik kurang menaruh minat dan bersemangat dalam melakukan gerakan teknik dasar passing kaki bagian dalam, (4) peserta didik belum berani mengajukan pertanyaan dan mengemukakan pendapat karena takut dan malu ditertawakan temanya jika salah terkait teknik dasar passing kaki bagian dalam, (5) kurangnya pemahaman peserta didik terhadap model pembelajaran kooperatif tipe NHT, (6) peserta didik kurang bersemangat dan besungguh-sungguh dalam melakukan teknik dasar passing kaki bagian dalam, (7) kurangnya kesempatan peserta didik dalam melakukan gerakan teknik dasar passing kaki bagian dalam sehingga hasilnya kurang maksimal.

Berdasarkan permasalahan-permasalahan yang dihadapi pada siklus I tersebut maka adapun solusinya yaitu: (1) bagi peserta didik yang kurang mendengarkan saat pemberian materi, peserta didik tersebut akan dipanggil kedepan untuk menjelaskan materi yang sudah 
diberikan, (2) memberikan penghargaan berupa nilai plus bagi peserta didik yang bersungguhsungguh pada saat melakukan gerakan teknik dasar passing kaki bagian dalam sehingga pandangan dapat mengarah ke depan, (3) memberikan pertanyaan mengenai materi yang sudah disampaikan agar peserta didik tidak ragu-ragu dalam menjawab pertanyaan yang di berikan, (4) mengimplementasi model pembelajaran kooperatif tipe NHT pada peserta didik secara lebih jelas dengan memberikan lembaran tahapan-tahapan pembelajaran kooperatif tipe NHT, (5) memberikan motivasi agar peserta didik menjadi lebih bersemangat dan bersungguh-sungguh dalam mengikuti pembelajaran pada siklus II tentang teknik dasar passing kaki bagian dalam, (6) membariskan peserta didik 2 bersaf agar peserta didik yang berada di belakang dapat memperhatikan lebih jelas mengenai materi yang disampaikan, (7) membagi peserta didik menjadi jumlah kelompok yang lebih banyak sehingga jumlah peserta didik dalam satu kelompok lebih sedikit sehingga kesempatan dalam melakukan gerakan di setiap peserta didik menjadi lebih banyak.

Pembelajaran pada siklus II berlangsung sangat kondusif, peserta didik sudah mengetahui dan mampu beradaptasi dengan model pembelajaran kooperatif tipe NHT. Hal ini terlihat dari aspek aktivitas belajar peserta didik, saat peneliti memperagakan gerakan tidak lagi hanya menonton tetapi aktif bertanya terhadap penjelasan peneliti di setiap tahap gerakan yang diperagakan oleh peneliti. Rata-rata aktivitas belajar teknik dasar passing kaki bagian dalam secara klasikal tergolong aktif. Sedangakan untuk penguasaan materi teknik dasar passing kaki bagian dalam berada dalam kategori baik. Peningkatan ini tidak terlepas dari implementasi model pembelajaran kooperatif tipe NHT secara optimal dengan perbaikanperbaikan pembelajaran sesuai dengan kekurangan-kekurangan yang terjadi pada siklus sebelumnya.

Berdasarkan uraian diatas, ini berarti tingkat ketuntasan hasil belajar teknik dasar passing kaki bagian dalam pada siklus II sudah memenuhi standar ketuntasan secara klasikal yaitu sebesar 70 sesuai dengan KKM di SMK Negeri 2 Singaraja. Peningkatan aktivitas dan hasil belajar pada siklus II tersebut dikarenakan: 1) penggunaan model pembelajaran kooperatif tipe NHT dengan pembelajaran berkelompok sudah dipahami oleh peserta didik dan 2) peneliti melakukan perbaikan berdasarkan kendala-kendala yang dialami pada siklus I.

Meskipun pelaksanaan siklus II dinyatakan berhasil, tetapi masih terdapat kendalakendala yang dihadapi saat penerapan model pembelajaran kooperatif tipe NHT, yaitu: terbatasnya waktu pelaksanaan penelitian sehingga peserta didik kekurangan waktu untuk lebih memahami tahapan-tahapan model pembelajaran yang peneliti terapkan. Dengan adanya kendala tersebut solusi yang peneliti sarankan kepada guru yaitu untuk selanjutnya agar lebih sering menerapkan model pembelajaran kooperatif tipe NHT dalam pembelajaran PJOK, sehingga peserta didik akan semakin paham dengan struktur pembelajaran dalam model pembelajaran kooperatif tipe NHT.

Dari sekian banyak model pembelajaran kooperatif yang ada, salah satunya adalah model pembelajaran kooperatif tipe NHT. Dimana dengan melihat aktivitas dan hasil belajar teknik dasar passing kaki bagian dalam ditemukan hasil bahwa dengan mengimplementasikan model pembelajaran kooperatif tipe NHT aktivitas dan hasil belajar peserta didik meningkat dalam materi teknik dasar passing kaki bagian dalam.

Berdasarkan data analisa hasil uraian diatas, bahwa aktivitas dan hasil belajar meningkat dikarenakan: (1) Peserta didik lebih aktif dalam mengikuti suatu proses pembelajaran dalam melakukan interaksi dengan teman sehingga pembelajaran lebih aktif dan tidak satu arah, (2) Timbulnya kerjasama antar peserta didik dengan peserta didik, tim atau teman didalam kelompoknya dapat menyelesaikan tugas gerak yang diberikan oleh guru, (3) Peserta didik memiliki rasa tanggung jawab sehingga peserta didik dapat mengerjakan tugas dengan baik dalam suatu proses pembelajaran di dalam kelompoknya, (4) Peserta didik mengamati apa yang dicontohkan oleh guru atau dari orang lain dalam suatu proses pembelajaran, dan (5) Rasa percaya diri peserta didik dalam melaksanakan tugas gerak yang diberikan oleh guru.

Berdasarkan penelitian yang sudah dilakukan, adapun keterbatasan dalam melakukan penelitian ini yaitu: keterbatasan waktu pelaksanaan penelitian yang dilakukan 2 siklus, agar tidak mengganggu dari kurikulum sekolah yang sudah dibuat. Berdasarkan hasil penelitian 
yang telah peneliti lakukan serta teori-teori pendukung hasil penelitian yang telah dipaparkan di atas dapat disimpulkan bahwa penerapan model pembelajaran kooperatif tipe NHT dapat meningkatkan aktivitas dan hasil belajar teknik dasar passing kaki bagian dalam pada peserta didik kelas X A5 SMK Negeri 2 Singaraja Tahun Pelajaran 2018/2019. Penelitian yang sudah dilaksanakan ini tidaklah selalu berjalan dengan lancar sesuai dengan yang diharapkan dan yang sudah direncanakan. Karena ada kendala-kendala yang dihadapi peneliti dalam menjalankan penelitian ini. Adapun kendala-kendala yang dihadapi adalah: (a) jumlah alatalat pendukung yang kurang dari jumlah kelompok belajar yang sudah direncanakan, (b) respon peserta didik untuk memahami materi lambat sehingga harus dijelaskan berulangulang.

Dari kendala-kendala yang dihadapi tersebut adapun yang dilakukan peneliti untuk memecahkannya sehingga penelitian yang dilakukan dapat berjalan dengan lancar diantaranya adalah: (a) menggunakan bola plastik agar siswa lebih banyak mencoba melakukan gerakan teknik dasar passing kaki bagian dlam (b) membentuk variasi gerakan agarpembelajaran lebih menyenangkan, dan (c) menjelaskan kembali secara berulang-ulang materi yang belum dimengerti.

\section{SIMPULAN DAN SARAN}

Berdasarkan hasil analisis data dan pembahasan di atas dapat ditarik simpulan sebagai berikut. 1)Aktivitas belajar teknik dasar passing kaki bagian dalam meningkat melalui implementasi model pembelajaran kooperatif tipe NHT pada siswa kelas X A5 SMK Negeri 2 Singaraja tahun pelajaran 2018/2019. 2)Hasil belajar teknik dasar passing kaki bagian dalam meningkat melalui implementasi model pembelajaran kooperatif tipe NHT pada siswa kelas X A5 SMK Negeri 2 Singaraja tahun pelajaran 2018/2019.

Berdasarkan simpulan di atas, dapat dikemukakan saran-saran sebagai berikut. 1) Guru PJOK hendaknya mengimplementasi model pembelajaran kooperatif tipe NHT sebagai salah satu alternatif pembelajaran karena terbukti dapat meningkatkan aktivitas dan hasil belajar teknik dasar passing kaki bagian dalam pada pesera didik. 2) Bagi sekolah dapat dijadikan sebagai pedoman dalam pembelajaran PJOK khususnya pada materi teknik dasar passing kaki bagian dalam guna meningkatkan aktivitas dan hasil belajar. 3) Diharapkan kepada peserta didik yang dijadikan subjek penelitian selanjutnya lebih memperhatikan dan memahami pembelajaran yang diberikan agar dapat menambah wawasan pengetahuan khususunya dalam pembelajaran materi teknik dasar passing kaki bagian dalam maupun pada pembelajaran yang lain. Dan 4) Guru atau peneliti lain diharapkan melakukan penelitian tindakan lanjutan dengan mengimplementasikan model pembelajaran kooperatif tipe NHT pada kompetensi dasar yang lain, untuk mengetahui bahwa model pembelajaran ini tidak hanya dapat diterapkan pada pembelajaran sepak bola, khususnya teknik dasar passing kaki bagian dalam.

\section{DAFTAR PUSTAKA}

Dimiyati dan Mudjiono. 2006. Belajar dan Pembelajaran. Jakarta: Rineka Cipta.

Hamalik. 2008. Proses Belajar Mengajar. Jakarta:Bumi Aksara.

Kanca, I Nyoman. 2010. Metodologi Penelitian Keolahragaan. Singaraja : Universitas Pendidikan Ganesha.

Nurhadi. 2004. Pembelajaran Kontekstual dan Penerapannya dalam KBK. Malang: Universitas Negeri Malang.

Nurkancana dan Sunartana. 1990. Evaluasi Hasil Belajar. Surabaya: Usaha Nasional.

Permendikbud no 65. 2013. Tentang Standar Isi Pendidikan Dasar dan Menengah. Jakarta: Kemendikbud. 
Sudjana. 2004. Penilaian Hasil Proses Belajar Mengajar. Bandung: Remaja Rosdakarya.

Sugiyanto. 1998. Perkembangan dan Belajar Motorik. Jakarta:Departemen Pendidikan dan Kebudayaan.

Trianto. 2007. Model-Model Pembelajaran Inovatif. Jakarta: Prestasi Pustaka Publisher.

Undiksha. 2013. Pedoman Penulisan Skripsi dan Tugas Akhir. Singaraja: Departemen Pendidikan Nasional Universitas Pendidikan Ganesha. 